\title{
A new method for the objective evaluation of postoperative pain
}

\author{
Jacek Karpe ${ }^{1}$, Aleksandra Misiołek ${ }^{2}$, Andrzej Daszkiewicz ${ }^{1}$, Hanna Misiołek ${ }^{1}$ \\ ${ }^{1}$ Department of Anaesthesiology and Intensive Therapy, Chair of Anaesthesiology, Intensive Therapy and \\ Emergency Medicine in Zabrze, Medical University of Silesia, Katowice \\ ${ }^{2}$ Studenckie Koło Naukowe Psychologia i Kultura, Wydział Nauk Społecznych, Akademia Jana Długosza \\ w Częstochowie
}

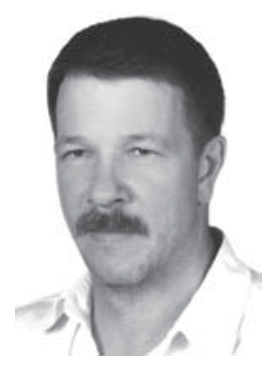

Kardiochirurgia i Torakochirurgia Polska 2013; 10 (1): 48-50

\begin{abstract}
Pain recognition, registration, and evaluation constitute fundamental problems of pain therapy. The only presently available method that allows for objective pain evaluation is the SCA (skin conductance algesimeter) method. In this method, skin conductance is the measurement of sympathetic nervous system activation caused by a pain stimulus. The activation of the sympathetic fibers that innervate sweat glands induces a release of the contents of these glands and a concurrent decrease in skin resistance and an increase in skin conductance. The presented method exhibits quick reaction to pain stimuli and does not depend on hemodynamic changes, temperature, breathing, neuromuscular blockade, catecholamine administration, or blood volume changes. It may be used in various fields of medicine in which severe pain and its objectification are phenomena that significantly influence the treatment's progress.

Key words: postoperative pain, objective pain evaluation.
\end{abstract}

The International Association for the Study of Pain defines pain as a "an unpleasant sensory and emotional experience associated with actual or potential tissue damage, or described in terms of such damage". The significance of the phenomenon of pain has been appreciated by the JCAHO (Joint Commission on Accreditation of Healthcare Organizations); the Commission now considers pain to be the fifth vital sign, and standards for its evaluation and treatment have been implemented in the USA and in European countries [1].

Experiencing pain is triggered by a maximal or submaximal stimulus specific for a given receptor type. Thus, a strong acoustic stimulus triggers pain localized by the patient as ear pain, significant light intensity results in eyeball pain, and violent irritation of the oral cavity mucosa recep-

\section{Streszczenie}

Jednym z najistotniejszych problemów w terapii bólu jest jego rozpoznanie i rejestracja oraz próba dokonania obiektywnej jego oceny. Jedyną współcześnie dostępną metodą pozwalającą na obiektywną ocenę nasilenia bólu jest metoda SCA (skin conductance algesimeter). W metodzie tej przewodnictwo skórne jest miarą pobudzenia układu współczulnego spowodowanego bodźcem bólowym. Aktywacja włókien współczulnych unerwiających gruczoły potowe indukuje uwolnienie ich zawartości i zmniejszenie oporu oraz zwiększenie przewodnictwa skórnego. Prezentowana metoda jest niezależna od zmian hemodynamicznych, temperatury, oddychania, środków zwiotczających, podaży katecholamin czy zmian objętości krwi. Metoda ta może mieć zastosowanie w wielu dziedzinach medycyny, w których silny ból i jego obiektywizacja są zjawiskiem istotnie wpływającym na przebieg leczenia.

Słowa kluczowe: ból pooperacyjny, obiektywna ocena bólu.

tors (e.g. by capsaicin) triggers strong tissue pain. Pain as a safety measure is also significant in terms of diagnosing and localizing the disease process.

Improperly treated, persistent acute pain results in the so-called neuroplasticity of the central nervous system (CNS). Due to progressing pathophysiological changes in the central nervous system, acute pain may turn into chronic pain, often neuropathic in nature, a pain syndrome which is difficult both to diagnose and to treat. Chronic pain has been defined as a pathological pain state without apparent biological value that has persisted beyond the normal tissue healing time. Hence the importance of effective pain diagnostics and proper analgesic proceedings during perioperative management, in order to inhibit the cascade of changes resulting from the pain stimulus. 
By stimulating the sympathetic nervous system, pain may lead to such changes as increased systolic heart rate, higher arterial blood pressure, increased cardiac oxygen consumption, and changes in the circumferential blood flow. Sympathetic nervous system stimulation also results in reduced motility of the gastrointestinal tract, the urinary bladder, and the urethra, as well as in a reflexive increase in muscle tension (so-called muscle guarding). Persisting pain related to thoracic and abdominal procedures is conducive to impaired lung ventilation and airway secretion retention. A long-lasting pain stimulus results in decreased insulin concentration and in increased concentrations of adrenocorticotropic hormone (ACTH), cortisol, catecholamines, aldosterone, renin, angiotensin, vasopressin, and glucagon. The consequences of the abovementioned changes include catabolism, hyperglycemia, negative nitrogen balance, and sodium retention. Changes in the endocrine system lead to depression of the immune system, increase infection risk, and impair tissue healing. Severe pain is also detrimental to the mental well-being of the patient, causing behavioral changes such as anxiety, helplessness, depression, or insomnia. Establishing whether behavioral changes are directly caused by severe pain is difficult when done by means of typical (somatic) vital signs analysis, and therefore such changes are an underestimated problem of the prolonged and complicated postoperative period. The issues summarized above indicate unequivocally that diagnosing and registering pain, as well as attempting to evaluate it objectively, constitute one of the most significant concerns in pain therapy [1-4].

The only presently available method which enables one to objectively evaluate the severity of pain is the SCA (skin conductance algesimeter) method, which was first presented in theory and practice by Professor Hanne Storm, et al. [5]. The method employed skin conductance as a measure for sympathetic nervous system stimulation by pain. The devices known as "lie detectors" operate in a similar manner.

The activation of the sympathetic fibers innervating the sweat glands induces the glands to release their content (so-called emotional sweating), while concurrently reducing the skin's resistance and increasing its conductance.

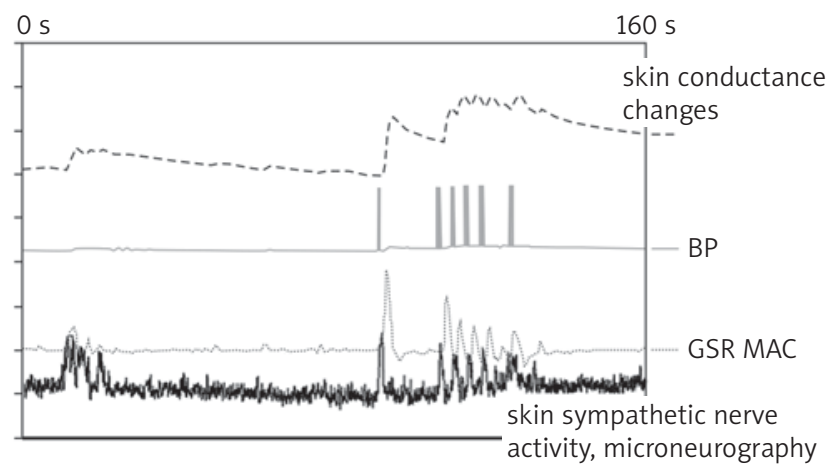

Fig. 1. Changes in skin conductance related to the stimulation of sympathetic fibers (Gjerstad AC, Storm H, Wallin G. Evaluation of the skin conductance method by using microneurography, ISAP, Chicago 06. Presentation of skin sympathetic nervous system)
Prompt absorption of the released sweat reduces the conductance again. The conductance difference which occurs in this manner is interpreted as a single oscillation, which has an intensity (wave amplitude) and slope (time duration between the peak and the trough). The extent of sympathetic nervous system stimulation is defined by amplitude (intensity) and frequency (the number of conductance fluctuations or oscillations in time) and is presented as their resultant in the form of an index (Fig. 1). The presented figure demonstrates the registered sympathetic skin neuron activity (the lower curve) and the relevant conductance index changes (the upper curve). Pain stimuli induce a swift emotional sweating increase and skin conductance fluctuation. As the pain stimulus ends, skin conductance decreases immediately. These changes are registered by electrodes attached to palmar or plantar skin, richly supplied with sweat glands. The conductance fluctuations created in this manner reach the analyzing unit, where they are converted and analyzed by means of appropriate software. The signal converted by the software is expressed in the form of an index, which corresponds to the "intensity" of pain stress (Table I). The demonstrated method exhibits a short reaction time (1-2 seconds) to pain stimuli and is not dependent on hemodynamic variability, environment temperature, or breathing rhythm. The SCA's operation is not influenced by neuromuscular blockade, catecholamine administration, or changes in blood volume. In relation to moderate to severe pain, the method exhibits sensitivity and specificity of $90 \%$ and its negative predictive value is $97 \%$. The sampling frequency of the signal reaching the recorder is $50 \mathrm{~Hz}$, and its resolution is 12 bits. The measurement range of the method is $1-200 \mathrm{mS}$ (microsiemens). In order to eliminate noise, the minimal amplitude is set at $0.02 \mathrm{mS}$ (microsiemens). In order to eliminate artifacts of the conductance wave slope, the minimal value for this parameter has been set at the level of $2 \mathrm{mS} / \mathrm{s}$ (microsiemens/second) [5-9].

The presented method may be applied in numerous fields of medicine in which pain and its objectivization are phenomena significantly influencing the progress of treatment. Unquestionably, acute pain after procedures involving thoracotomy (cardiac and thoracic surgery) is treated as pain of the strongest intensity. The extent and location of the surgery determine that the strongest discomfort is experienced for more than 3 days, and the pain, subjectively

Tab. I. The scale and index of pain stress intensity (according to H. Storm)

\begin{tabular}{ll}
\hline $\begin{array}{l}\text { WHITE: } \\
0.00-0.07 \text { impulse/s }\end{array}$ & Patient without pain \\
\hline $\begin{array}{l}\text { LIGHT YELLOW: } \\
0.13-0.21 \mathrm{impulse} / \mathrm{s}\end{array}$ & Patient without pain (NRS < 4) \\
\hline $\begin{array}{l}\text { YELLOW } \\
0.27 \text { impulse/s }\end{array}$ & $\begin{array}{l}\text { Active patient, possibly experiencing pain } \\
\text { (NRS 4-5) }\end{array}$ \\
\hline $\begin{array}{l}\text { ORANGE: } \\
\text { 0.33 impulse/s }\end{array}$ & $\begin{array}{l}\text { The patient probably experiences pain } \\
\text { (NRS 6-8); assess the situation }\end{array}$ \\
\hline $\begin{array}{l}\text { RED: } \\
0.40-0.70 \text { impulse/s }\end{array}$ & $\begin{array}{l}\text { The patient most likely experiences pain } \\
\text { (NRS 8-10); try to help }\end{array}$ \\
\hline
\end{tabular}


assessed according to the VAS (visual analogue scale) or the PHHPS (Prince Henry Hospital Pain Score), is evaluated at more than 4-5 points. The discussed procedures have been classified as categories III and IV, which entails that pain relief after these procedures is difficult and multimodal, and it requires a significant effort on the part of the hospital's pain treatment team. It is after these procedures that the chronic pain phenomenon occurs most often and it most frequently constitutes a severe complication of improperly treated postoperative pain $[1,10]$. A device for the objective evaluation of severe pain may be of great help in the evaluation of pain, the selection of drugs, and the choice of their dosage, so that efficacious treatment does not contribute to the intensity of side effects and complications arising from using a variety of drugs in the course of the treatment. The possibility of objectivizing acute pain evaluation in children, including neonates, undergoing extensive dissections, raises high hopes among the personnel of pediatric surgery facilities.

\section{References}

1. Misiołek H, Mayzner-Zawadzka E, Dobrogowski J, Wordliczek J. Zalecenia postępowania w bólu ostrym i pooperacyjnym. Ból 2011; 12(2): 9-33.

2. Warfield CA, Kahn CH. Acute pain management. Programs in U.S. hospitals and experiences and attitudes among U.S. adults. Anesthesiology 1995; 83: 1090-1094.
3. Brodner G, Mertes N, Buerkle H, Marcus MA, Van Aken H. Acute pain management; analysis, implications and consequences after prospective experience with 6349 patients. Eur J Anaesthesiol 2000; 17: 566-575.

4. Kehlet $\mathrm{H}$. Acute pain control and accelerated postoperative surgical recovery. Surg Clin North Am 1999; 79: 431-443.

5. Storm H, Shafiei M, Myre K, Raeder J. Palmar skin conductance compared to a developed stress score and to noxious and awakeness stimuli on patients in anaesthesia to study the sensitivity and specificity of skin conductance. Acta Anaesthesiol Scand 2005; 49: 798-804.

6. Ledowski T, Paech MJ, Storm H, Jones R, Schug SA. Skin conductance monitoring compared with bispectral index monitoring to assess. $\mathrm{Br} J$ Anaesth 2006; 97: 187-191.

7. Storm H. Development of emotional sweating in the preterm infant measured by skin conductance. Early Hum Dev 2001; 62: 149-158.

8. Storm H. Changes in skin conductance as a tool to monitor nociceptive stimulation and pain. Curr Opin Anaesthesiol 2008; 21: 796-804.

9. Tsui SL, Fok M, Lo J-R, Yang J. Postoperative analgesia reduces mortality and morbility after esophagectomy. Am J Surg 1997; 173: 472-478.

10. Misiołek H, Białka S, Kucewicz-Czech E. Oksykodon - nowa alternatywa w terapii bólu pooperacyjnego w kardiochirurgii i torakochirurgii. Kardiochir Torakochir Pol 2012; 9: 69-72. 